\title{
SCHIP1 Gene
}

National Cancer Institute

\section{Source}

National Cancer Institute. SCHIP1 Gene. NCI Thesaurus. Code C98078.

This gene may play a role in signaling. 